\title{
Rabbit Fibroma
}

National Cancer Institute

\section{Source}

National Cancer Institute. Rabbit Fibroma. NCI Thesaurus. Code C133740.

Fibroma that occurs in a rabbit. 